\title{
PENGARUH MODEL PBL (PROBLEM BASED LEARNING) DENGAN MENGGUNAKAN MEDIA PETA PIKIRAN TERHADAP HASIL BELAJAR SISWA PADA MATERI POKOK GERAK LURUS KELAS X SEMESTER I SMA NEGERI 1 PANTAI CERMIN T.P 2014/2015
}

\author{
Shabrina Amalia dan Mara Bangun Harahap \\ Jurusan Fisika FMIPA Universitas Negeri Medan \\ Jalan Willem Iskandar Pasar V Medan, Sumatera Utara \\ anashabrina92@gmail.com
}

\begin{abstract}
ABSTRAK
Penelitian ini bertujuan untuk mengetahui pengaruh model PBL (Problem Based Learning) dengan menggunakan media peta pikiran terhadap hasil belajar siswa pada materi pokok gerak lurus kelas X semester I SMA Negeri 1 Pantai Cermin T.P. 2014/2015. Jenis penelitian ini adalah kuasi eksperimen. Populasi dalam penelitian ini adalah seluruh siswa kelas X Semester ganjil SMA Negeri 1 Pantai Cermin terdiri dari empat kelas. Sampel penelitian ini diambil dua kelas yaitu kelas X-1 (sebagai kelas eksperimen) dan kelas X-2 (sebagai kelas kontrol) yang masing-masing berjumlah 34 dan 35 siswa ditentukan dengan cluster random sampling. Kemudian diberikan perlakuan yang berbeda, kelas eksperimen dengan model PBL (Problem Based Learning) dengan menggunakan media peta pikiran dan kelas kontrol dengan pembelajaran konvensional. Data yang digunakan dalam penelitian ini digunakan tes essay jumlah soal 10 item yang telah divalidkan oleh validator. Melalui uji hipotesis satu pihak diperoleh hasil belajar siswa dengan menggunakan model PBL (Problem Based Learning) lebih baik daripada pembelajaran konvensional.
\end{abstract}

Kata Kunci : PBL (Problem Based Learning), Gerak lurus, Media peta pikiran, Hasil belajar siswa.

\begin{abstract}
This study aimed to determine the effect of the model of PBL (Problem Based Learning) by using mind maps media on learning outcomes of students in the subject matter of straight motion in the first semester of class X SMA Negeri 1 Pantai Cermin TP 2014/201. This research is a quasiexperiment. The population in this study are all class $X S M A$ Negeri 1 Pantai Cermin consists of four classes. The study sample was taken two classes of class $X-1$ (as an experimental class) and Class $X-2$ (as a control class), each of which total amount of 34 and 35 students were determined by cluster random sampling. Then given a different treatment, the experimental class with the model PBL (Problem Based Learning) by using mind maps and media control class with conventional learning. The data used in this study used a test essay question number 10 items that have
\end{abstract}


been validated. Through hypothesis testing of the student learning results it is obtained that using the model PBL (Problem Based Learning) better than conventional learning.

\section{Keywords : PBL (Problem Based Learning), Motion straight, media mind maps, student learning outcomes.}

\section{PENDAHULUAN}

Proses pembelajaran terutama di dalam kelas diarahkan kepada kemampuan anak untuk menghafal informasi, otak anak dipaksa untuk mengingat dan menimbun berbagai informasi tanpa dituntut untuk memahami informasi yang disajikan. Rendahnya minat siswa dalam belajar terutama mata pelajaran Fisika menyebabkan kurangnya gairah belajar siswa sehingga menyebabkan kurangnya intensitas belajar siswa. Fisika sebenarnya bukanlah ilmu yang abstrak dan jauh dari kehidupan sehari hari. Banyak pengaplikasian ilmu fisika yang dengan mudah dapat kita temukan dalam kehidupan sehari-hari.

Berdasarkan pengalaman penulis saat melaksanakan Program Pengalaman Lapangan Terpadu (PPLT), guru hanya mengajar dengan menggunakan model pembelajaran konvensional, yaitu menjelaskan di depan kelas, kemudian siswa bertugas untuk menyelesaikan soalsoal. Hal ini menyebabkan siswa menjadi pasif dan tidak memahami konsep dasar dan penerapannya dalam kehidupan sehari-hari. Hal inilah yang menyebabkan hasil belajar siswa masih jauh dari yang diharapkan.

Berdasarkan hasil observasi dengan menggunakan angket yang disebar pada 34 siswa, diperoleh data bahwa 3 siswa mengatakan fisika itu mudah. 17 orang mengatakan fisika itu sulit dan kurang menarik dan selebihnya 14 orang mengatakan fisika itu biasa saja. Dari data ini terlihat bahwa sebagian besar siswa tidak menyukai mata pelajaran fisika. Setelah dilakukan wawancara dengan seorang guru Fisika SMA Negeri 1 Pantai Cermin, diperoleh informasi bahwa nilai rata-rata siswa dalam mata pelajaran fisika tergolong rendah. Ketuntasan Kompetensi Minimal (KKM) di sekolah tersebut untuk mata pelajaran fisika adalah 7,5 . Sedangkan hasil ujian yang dilaksanakan pada tanggal 10-15 Maret 2014 menunjukkan kurang dari $50 \%$ siswa yang berhasil mencapai KKM. Ada beberapa model pembelajaran yang diketahui oleh guru yang mengajar, seperti model kooperatif, tetapi sangat jarang digunakan. Guru lebih sering menjelaskan di depan kelas, kemudian memberi banyak contoh soal dan latihan-latihan.

Rendanya hasil belajar siswa selama ini, menunjukkan bahwa seorang guru harus menggunakan model pembelajaran yang bervariasi di dalam kelas yang disesuaikan dengan materi dan kemampuan siswa, sehingga siswa bisa berperan aktif dan kreatif. Salah satu alternatif yang dapat digunakan untuk mengatasi masalah rendahnya hasil belajar siswa adalah menciptakan suasana belajar yang dapat menghubungkan kita dalam kehidupan sehari-hari. Model PBL (Problem Based Learning) adalah salah satu solusinya, model ini dapat membuka cakrawala berpikir siswa serta mengembangkan kemampuan 
siswa untuk dapat menyelesaikan masalah yang ada dalam kehidupan sehari-hari. Penggunaan model PBL akan lebih efektif jika didukung dengan penggunaan media peta pikiran. Peta pikiran adalah metode mencatat kreatif yang memudahkan mengingat banyak informasi. Catatan yang dibuat membentuk sebuah pola gagasan yang saling berkaitan, dengan topik utama di tengah dan perincian menjadi cabang-cabangnya. Peta pikiran merupakan teknik yang paling baik dalam membantu proses berpikir otak secara teratur karena menggunakan teknik grafis yang berasal dari pemikiran manusia yang bermanfaat untuk menyediakan kunci-kunci universal sehingga membuka potensi (Tonny, dkk., 2004: 68). Penelitian yang terkait tentang model PBL (Problem Based Learning) telah dilakukan oleh Lubis (2012) yang mendapatkan hasil belajar sebelum menerapkan model PBL (Problem Based Learning) adalah 46,14 sedangkan rata-rata hasil belajar setelah menerapkan model PBL (Problem Based Learning) adalah 68,14 . Artinya ada perbedaan yang signifikan ketika siswa diajarkan dengan menggunakan model PBL (Problem Based Learning). Selain itu, Pohan (2012) juga pernah melakukan penelitian dengan menggunakan model PBL (Problem Based Learning) yang hasilnya terdapat perbedaan hasil belajar siswa pada kelas eksperimen dan kelas kontrol. Dimana pada kelas eksperimen nilai rata-rata siswa adalah 60,43 lebih baik dibandingkan dengan kelas control menghasilkan nilai rata-rata 54,43.

Namun ada perbedaan antara penelitian yang sebelumnya dengan penelitian yang akan dilaksanakan. Penelitian yang sebelumnya tidak menggunakan media peta pikiran dalam penggunaan model PBL (Problem Based Learning). Dalam hal ini peneliti akan memaksimalkan hasil belajar dengan model pembelajaran PBL (Problem Based Learning) dengan menggunakan media peta pikiran, karena peta pikiran dapat membantu siswa menangkap pikiran dan gagasan pada kertas dengan menggunakan gambar, warna, dan simbol yang jelas, lengkap dan mudah untuk membuat informasi lebih mudah dimengerti dan diingat kembali dalam memaksimalkan momen belajar.

\section{METODE PENELITIAN}

Penelitian ini dilaksanakan di dilaksanakan di SMA Negeri 1 Pantai Cermin dengan populasi seluruh siswa kelas X SMA Negeri 1 Pantai Cermin yang terdiri dari lima kelas. Teknik pengambilan sampel dilakukan dengan cara teknik cluster random sampling. Sampel dalam penelitian ini terdiri dari dua kelas yaitu $\mathrm{X}_{1}$ kelas eksperimen dengan menggunakan model PBL (Problem Based Learning) dengan menggunakan peta pikiran dan $\mathrm{X}_{2}$ sebagai kelas kontrol dengan menggunakan pembelajaran konvensional.

Jenis penelitian ini adalah kuasi eksperimen, yaitu penelitian yang bertujuan untuk mengetahui akibat yang dikenakan pada suatu subjek. Pengaruh yang dimaksud adalah hasil belajar siswa yang menerapkan model pembelajaran yang telah ditentukan dapat dilihat dari hasil belajar siswa melalui tes hasil belajar. Penelitian ini melibatkan dua kelas yang diberi perlakuan yang berbeda. Satu kelas sebagai kelas eksperimen dan kelas 
lainnya sebagai kelas kontrol. Desain penelitian ini dapat dilihat pada Tabel 1.

Tabel 1. Two Group Pretets-Postest Design

\begin{tabular}{|l|c|c|c|}
\hline Kelas & Pretes & Perlakuan & Postes \\
\hline Eksperimen & $\mathrm{T}$ & $\mathrm{X}_{1}$ & $\mathrm{~T}$ \\
\hline Kontrol & $\mathrm{T}$ & $\mathrm{X}_{2}$ & $\mathrm{~T}$ \\
\hline
\end{tabular}

Keterangan:

$\mathrm{T}=$ Instrumen tes hasil belajar diberikan kepada kelas eksperimen dan kelas kontrol.

$\mathrm{X}_{1}=$ Pembelajaran dengan menerapkan model pembelajaran berbasis masalah

$\mathrm{X}_{2}=$ Pembelajaran dengan menerapkan pembelajaran konvensional

Instrumen yang digunakan dalam penelitian adalah tes hasil belajar siswa pada materi pokok gerak lurus berjumlah 10 soal dalam bentuk uraian dan diberikan sebanyak 2 kali yaitu pretes dan postes. Instrumen yang telah disusun kemudian divaliditaskan kepada ahli yaitu 2 orang dosen di jurusan Fisika. Setelah data pretes diperoleh, dilakukan analisis data dengan uji normalitas dengan uji Chi Kuadrat dan uji homogenitas dengan uji kesamaan varians. Setelah itu dilakukan pengujian hipotesis uji dua pihak untuk mengerahui kemampuan awal siswa pada kedua kelompok sampel. Selanjutnya peneliti mengajarkan materi pelajaran dengan menggunakan model PBL (Problem Based Learning) dengan menggunakan media Peta Pikiran pada kelas eksperimen dan pembelajaran konvensional pada kelas kontrol. Untuk mengetahui hasil akhirnya maka dilakukan postes menggunkan uji hipotesis untuk mengetahui pengaruh perlakuan model model PBL (Problem Based Learning) dengan menggunakan media Peta Pikiran terhadap hasil belajar siswa.

\section{HASIL DAN PEMBAHASAN Hasil Penelitian}

Data yang dideskripsikan pada penelitian ini meliputi data hasil belajar fisika pada materi gerak lurus, yang diberikan perlakuan berbeda yaitu 1) pembelajaran berbasis masalah dengan menggunakan media peta pikiran, 2) pembelajaran dengan menggunakan model konvensional. Data hasil belajar siswa dapat dilihat sebagai berikut

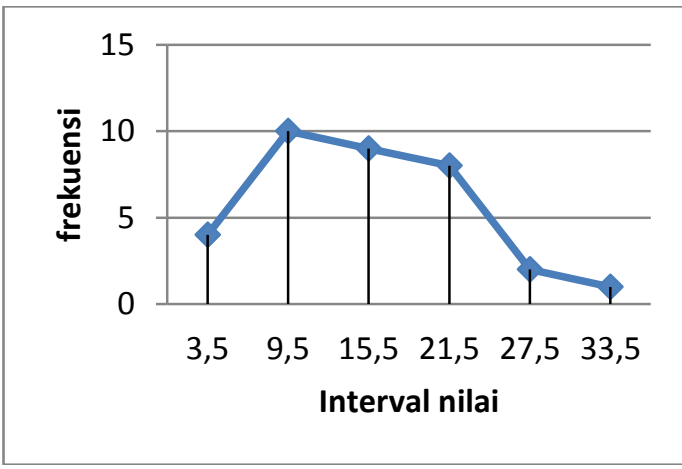

Gambar 1 Poligon frekuensi nilai pretes kelas eksperimen

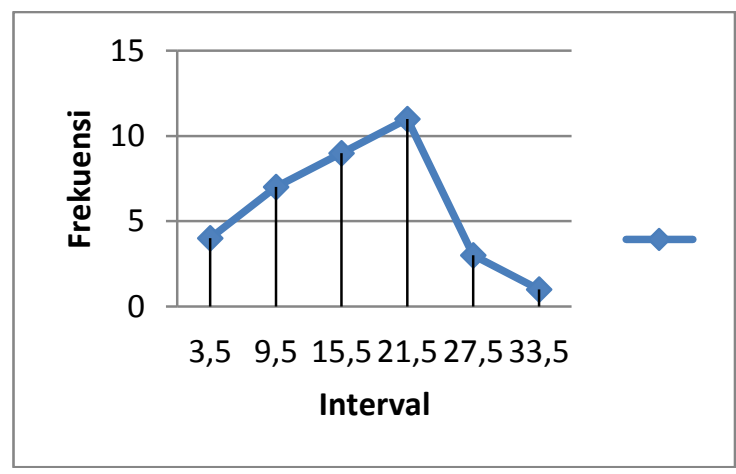

Gambar 2 Poligon frekuensi nilai pretes kelas kontrol

Gambar 1 dan 2 histogram frekuensi menunjukkan lebar setiap batangnya merupakan panjang 
interval kelas, batas tepinya merupakan batas bawah dan batas atas kelas, dan tingginya menunjukkan frekuensi setiap kelas interval. Poligon frekuensi menunjukkan nilai tengah kelas interval, dan kurva frekuensi mendekati bentuk model kurva normal yang menunjukkan karakteristik dari populasi yaitu mendekati distribusi normal.

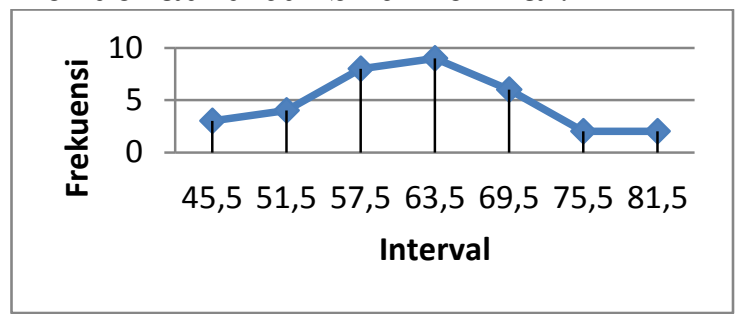

Gambar 3 Poligon frekuensi nilai postes kelas eksperimen

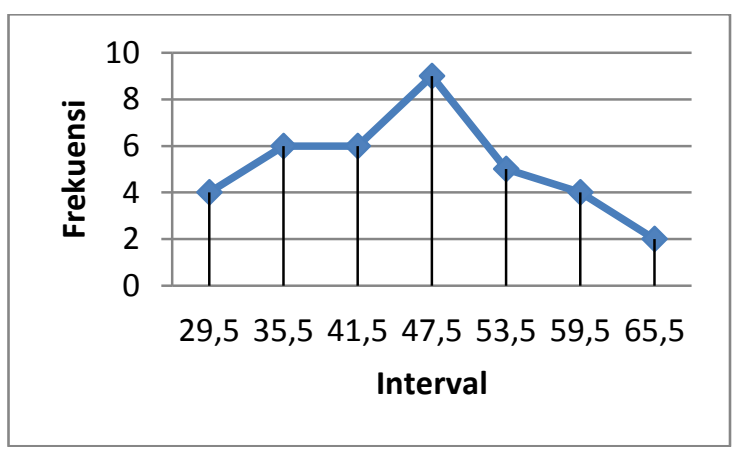

Gambar 4 Poligon frekuensi nilai postes kelas control

Gambar 3 dan 4 histogram frekuensi menunjukkan lebar setiap batangnya merupakan panjang interval kelas, batas tepinya merupakan batas bawah dan batas atas kelas, dan tingginya menunjukkan frekuensi setiap kelas interval. Poligon frekuensi menunjukkan nilai tengah kelas interval, dan kurva frekuensi mendekati bentuk model kurva normal yang menunjukkan karakteristik dari populasi yaitu mendekati distribusi normal.

Hasil penelitian menunjukkan bahwa peningkatan hasil belajar siswa didukung oleh aktivitas siswa dalam proses pembelajaran. Data penilaian aktivitas siswa diperoleh dari pengamatan yang dilakukan oleh pengamat kepada siswa kelas eksperimen dan kelas kontrol pada setiap pertemuan kegiatan pembelajaran yaitu sebanyak tiga kali pertemuan. Nilai rata-rata aktivitas siswa pada kelas eksperimen dan kelas kontrol sebagai berikut

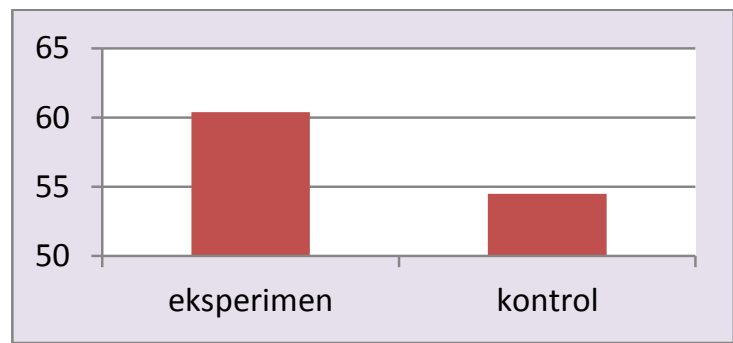

Gambar 5 nilai rata-rata aktivitas kelas eksperimen dan kelas kontrol

Peningkatan hasil belajar siswa tidak hanya didukung oleh aktivitas siswa, tetapi juga didukung oleh keterampilan siswa dalam proses pembelajaran. Keterampilan yang diamati dalam penelitian adalah mempersiapkan alat dan bahan, merancang percobaan, dan pengamatan.

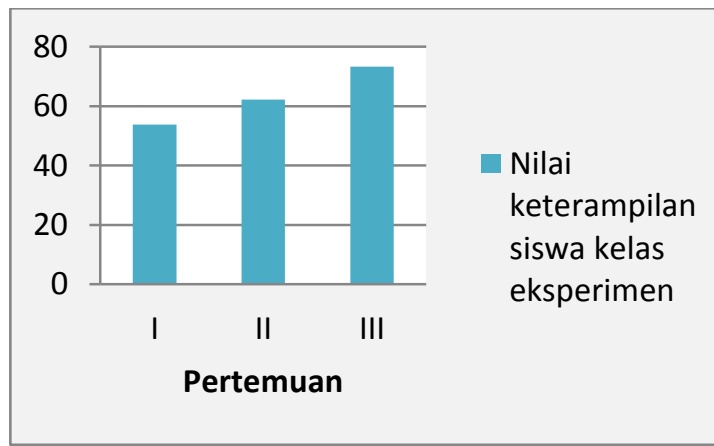

Gambar 6 Nilai keterampilan siswa kelas eksperimen

\section{Pembahasan}

Berdasarkan data penelitian dapat dilihat pada kelas eksprimen 
yang diajar dengan menggunakan model PBL (Problem Based Learning) diperoleh hasil nilai rata-rata pretesnya 17,74 sedangkan nilai ratarata postes adalah 63,68. Sedangkan pada kelas kontrol yang diajar dengan menggunakan pembelajaran konvensional diperoleh hasil nilai rata-rata pretestnya 18,71 sedangkan nilai rata-rata postes adalah 48,97. Peningkatan hasil belajar siswa dikelas eksperimen ini dikarenakan pada saat proses belajar mengajar dengan menggunakan model PBL (Problem Based Learning) menggunakan media peta pikiran, dimana media peta pikiran tersebut berisi berbagai masalah yang berkaitan dalam kehidupan seharihari sesuai materi pembelajaran dan siswa dituntut untuk bekerja sama dalam memecahkan masalah tersebut dan menemukan sendiri informasi yang berkaitan dengan masalah, dan disini siswa dapat berpikir lebih cepat. Hal yang sama juga disampaikan oleh Fauzi (2012) dalam penelitiannya bahwa model pembelajaran berbasis masalah merujuk pada keaktifan siswa untuk bereksplorasi mengumpulkan dan menganalisis data untuk memecahkan masalah, sehingga dalam proses pembelajaran berbasis masalah siswa tidak hanya berperan sebagai penerima pelajaran melalui penjelasan guru secara verbal.

Model PBL (Problem Based Learning) dapat memberikan kesempatan pada siswa bereksplorasi mengumpulkan dan menganalisis data untuk memecahkan masalah, sehingga siswa mampu untuk berpikir kreatif, menyampaikan pendapat (kritis), memiliki rasa ingin tahu dalam menemukan alternatif pemecahan masalah. dengan berbantukan media peta pikiran yang menjelaskan materi-materi yang dimulai dari pusat permasalahan yang terjadi didalam lingkungan siswa. Maka Siswa dalam hal ini aktif dan antusias untuk bekerja sama dengan teman satu kelompok dalam menyelesaikan masalah yang telah diberikan oleh peneliti. Siswa juga tertarik dan aktif saat berdiskusi dan mengeluarkan pendapat yang berbeda saat diadakan diskusi antar kelompok. Pada tahap orientasi siswa pada masalah (pertama), peneliti memotivasi siswa dengan memberikan tujuan pembelajaran yang akan dicapai oleh siswa dan pada tahap ini peneliti memberikan masalah kepada siswa dengan memberikan pertanyaan sederhana yang berbeda didalam kehidupan sehari-hari siswa. Pada tahap mengorganisasi siswa untuk belajar (kedua), peneliti memberikan materi pelajaran dengan bantuan media peta pikiran yang dipelajari kemudian membentuk kelompok-kelompok belajar dan melakukan percobaan (eksperimen). Pada tahap penyelidikan individual maupun kelompok (ketiga), peneliti membimbing setiap siswa untuk mengumpulkan informasi untuk memecahkan masalah, dan melakukan percobaan (eksperimen) sekali lagi. Pada tahap mengembangkan dan mempresentasikan artefak dan exhibit (keempat), peneliti membantu setiap kelompok menyelesaikan dan menjawab semua permasalahan yang ada, serta mempersentasikan hasil diskusi kelompok yang sudah disiapkan, kemudian kelompok yang lain diberikan kesempatan memberikan pendapat atau masukan. Pada tahap menganalisis dan mengevaluasi proses mengatasi 
masalah (kelima), peneliti membantu siswa dalam mengkaji ulang pemecahan masalah sesuai dengan tujuan pembelajaran dan memberikan penguatan pada pemecahan masalah tersebut dan pada tahap ini peneliti membuat tes evaluasi untuk mengetahui pemahaman siswa.

Walaupun penggunakan model pembelajaran berbasis masalah dapat meningkatkan hasil belajar, nilai sikap dan keterampilan siswa, tetapi masih belum mencapai KKM. Hal ini dikarenakan selama pembelajaran masih ada kendala yang dihadapi peneliti yang menyebabkan pencapaian hasil belajar belum maksimal yaitu pelaksanaan semua tahap-tahap dalam model pembelajaran berbasis masalah kurang efektif karena keterbatasan peneliti dalam mengalokasikan waktu sesuai RPP, kurangnya pengalaman peneliti dalam mengelola kelas sehingga kondisi siswa yang ribut menyebabkan penelitian menjadi kurang efisien.

\section{KESIMPULAN DAN SARAN}

Kesimpulan

Berdasarkan hasil analisis dan uji statistik serta pembahasan maka kesimpulannya sebagai berikut (1) Pembelajaran dengan model Berbasis Masalah dengan menggunakan media mind map sebelum diberikan perlakuan rata-rata pretes sebesar 17,74 dan setelah diberikan perlakuan rata-rata postes siswa sebesar 63,68. (2) Pembelajaran secara Konvensional sebelum diberikan perlakuan rata-rata pretes sebesar 18,71 dan setelah diberikan perlakuan rata-rata postes siswa sebesar 48,97. (3) Terdapat pengaruh model Pembelajaran Berbasis Masalah dengan menggunakan media mind map terhadap hasil belajar siswa pada materi Gerak Lurus kelas $\mathrm{X}$ semester 1 di SMA Negeri 1 Pantai Cermin.

\section{Saran}

Berdasarkan hasil penelitian dan kesimpulan di atas, maka sebagai tindak lanjut dari penelitian ini disarankan bagi peneliti selanjutnya hendaknya lebih memahami bagaimana mengambil masalah, lebih berusaha untuk memotivasi siswa terhadap masalah dalam kehidupan sehari-hari, serta melakukan pembimbingan yang penuh pada saat melakukan praktikum.

\section{DAFTAR PUSTAKA}

Adiyatmaningsih, N. P. H., (2014), Jurnal Mimbar PGSD Universitas Ganesha, Model Pembelajaran Berbasis Masalah Berbantuan Mind Mapping Berpengaruh Terhadap Hasil Belajar IPA Siswa kelas V SD Gugus III Gianyar, vol: 2 No: 1 Tahun 2014

Anderson dan David, (2010), Pembelajaran, Pengajaran, dan Asesmen, Yogyakarta, Pustaka Pelajar

Arends, Richard I., (2007), Learning To Teach, Yogyakarta, Pustaka Pelajar

Arikunto, S., (2010), Prosedur Penelitian, Jakarta, Penerbit Rineka Cipta

Arikunto, S., (2012), Dasar-Dasar Evaluasi Pendidikan, Jakarta, Penerbit Bumi Aksara

Aziz, Benni, (2010), Penerapan Metode Pembelajaran Peta Pikiran untuk Meningkatkan Hasil Belajar Siswa Pada Materi Pokok Getaran dan Gelombang di Kelas Viii Semester II Smp Negeri 12 
Binjai T.A. 2009/2010, Medan, UNIMED

Buzan, Tony, (2004), Mind Map untuk Meningkatkan

Kreativitas, Penerbit PT

Gramedia Pustaka Utama

Dahar, Ratna Wilis, (2011), TeoriTeori Belajar \& Pembelajaran, Jakarta, Erlangga

Djamarah dan Zain, (2006), Strategi Belajar Mengajar, Jakarta, Penerbit Rineka Cipta

Husnah, M, (2013), Pengaruh Model Pembelajaran Berdasarkan Masalahberbantuan Komputer Terhadap Hasil Belajar Siswa pada Materi Pokok Listrik Dinamis Kelas X SMA Negeri 16 Medan T.P 2012/2013, Medan, UNIMED

Istarani, (2012), 58 Model Pembelajaran Inovatif, Medan, Media Persada

Jauhari, M., (2011), Implementasi PAIKEM, Jakarta, Prestasi Putaka Publisher

Lubis, L.H, (2012), Pengaruh Model Pembelajaran Berdasarkan MAsalah Pada Materi Pokok Listrik Dinamis Kelas $X$ Semester 2 Di SMA Negeri 1 Labuhan Deli Tahun Pelajaran 2011/2012, Medan, FMIPA UNIMED

Pohan, A.F, (2012), Pengaruh Model Pembelajaran Berbasis Masalahterhadap Hasil Belajar Siswa pada Materi Pokok Listrik Dinamis Kelas IX SMP $N \quad 5 \quad$ Pematangsiantar T.P 2012/2013, Medan, UNIMED

Sadirman, (2011), Interaksi \& Motivasi Belajar Mengajar, Jakarta, Rajawali Pers

Sagala, Saiful, (2009), Konsep Dan Makna Pembelajaran, Alfabeta, Bandung
Sanjaya, Wina, (2011), Kurikulum dan Pembelajaran, Jakarta, Kencana

Sudjana, (2005), Metoda Statistika, Bandung, Tarsito Trianto, (2009), Mendesain Model Pembelajaran Inovatif-Progresif, Jakarta, Kencana 